\title{
A new Early Silurian turbidite system in Central Wales: insights into eustatic and tectonic controls on deposition in the southern Welsh Basin
}

\author{
D. I. SCHOFIELD*†, J. R. DAVIES*, R. A. WATERS $\ddagger$, M. WILliAMS $\S \& D$. WILSON* \\ ${ }^{*}$ British Geological Survey, Kingsley Dunham Centre, Keyworth, Nottinghamshire, NG12 5GG, UK \\ †Department of Geology, National Museum of Wales, Cathays Park, Cardiff, CF10 3NP, UK \\ $\S$ Department of Geology, University of Leicester, University Road, Leicester, LE1 7RH, UK
}

(Received 10 October 2007; accepted 12 April 2008; First published online 10 September 2008)

\begin{abstract}
The newly recognized Nant Brianne turbidite system was a focus of laterally supplied coarse-grade sediment deposition that, along with the Caban-Ystrad Meurig system, punctuated late Hirnantian to early Telychian, mudstone-dominated slope apron deposition along the SE margin of the southern Welsh Basin. Geological mapping coupled with detailed biostratigraphy enable the depositional influence of sea-floor topography, an active Llyn Brianne Fault and eustatic sea-level changes to be tracked. The latter may represent 'far field' effects relating to the retreat and advance of contemporary Gondwanan ice sheets. Slope apron mudstone facies reveal a strong response to high order eustatic events; however, the response of contemporary, easterly sourced, coarse-grade turbidite systems was more complex, with some periods of increased sand and gravel input coinciding with times of rising global sea level. These anomalous relationships are explained by invoking a series of smaller-scale movements in marine base level. It was the interaction of these lower order events with the main eustatic cycles that appears to have been the primary control on sand and gravel input to the Welsh Basin. An early Telychian expansion of the Nant Brianne turbidite system records a marked increase in tectonically generated sediment at a time of palaeo-plate collision between Baltica/Avalonia and Laurentia before intra- and peri-basinal faulting led to its abandonment as a supply path to the basin centre.
\end{abstract}

Keywords: Silurian, Llandovery, Wales, turbidite.

\section{Introduction}

The Welsh Basin is regarded as an ensialic marginal marine basin that formed during the contraction of the adjacent Iapetus and Rheic oceans during the Early Palaeozoic Caledonian orogenic cycle (e.g. Cocks \& Fortey, 1982; Soper \& Hutton, 1984; Soper \& Woodcock, 2003; Woodcock, Soper \& Strachan, 2007). It is characterized by high subsidence rates that accommodated a thick sequence of basinal sediments (Woodcock et al. 1996), and contrasts markedly with the contemporaneous, relatively stable, Midland Platform to the east (Woodcock \& Gibbons, 1988).

During deposition of the latest Ashgill to middle Llandovery series, between around 445 and $430 \mathrm{Ma}$ (after Melchin, Cooper \& Sadler, 2004), the southern Welsh Basin recorded the development of a broad NWfacing slope apron, constructed principally from turbiditic and hemipelagic mudstones supplied from the east (Ball et al. 1992; Davies et al. 1997), that extended west from the Tywi Lineament, a contemporaneous structural high separating basinal and shelfal domains (Fig. 1; Woodcock, 1984). Locally punctuating this mudstone-dominated succession are several small-

$\nmid$ †uthor for correspondence: dis@bgs.ac.uk scale bodies of conglomerate and sandstone turbidites, also sourced from the east (Fig. 1; Morton et al. 1992). These define narrow submarine corridors via which coarse clastic sediment was routed across the proximal parts of the slope apron, as well as lobelike constructional features of similar material on the slope apron surface (Cave \& Hains, 1986; Davies \& Waters, 1995). As with many modern systems (e.g. Pickering, Hiscott \& Hein, 1989), the confined nature of the proximal parts of these coarse-grade sediment bodies suggests a point source that was linked, via the adjacent shelf, to a contemporary fluvial system.

The changes in facies architecture and depositional style of these turbidite systems are thought to reflect tectonically and eustatically driven sea-level changes (e.g. Davies et al. 1997). Unravelling these influences provides insights into the nature and timing of both palaeo-plate interactions (e.g. Cocks \& Torsvik, 2002) and global climatic variation during Early Palaeozoic times (e.g. Loydell, 1998; Page et al. 2007 and references therein).

Tectonically driven sea-level changes in the Welsh Basin were controlled by oblique terminal collision of the palaeocontinents of Baltica, Laurentia and Avalonia, marked in the Welsh Basin by transtensional basin development that came to an end with the final 


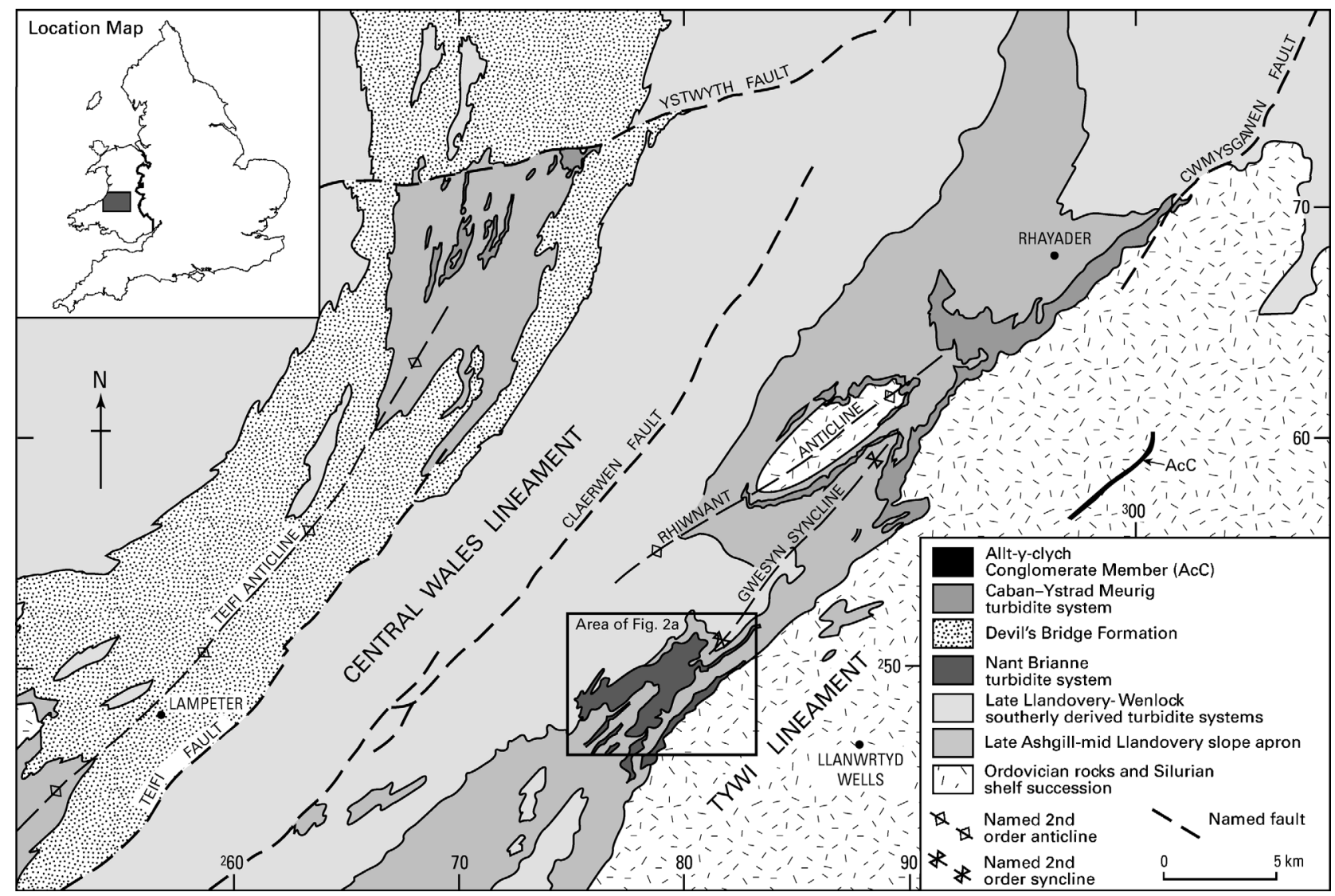

Figure 1. Geological sketch map of part of Central Wales, illustrating the location and setting of the late Ordovician to early Silurian basinal coarse clastic sequences considered herein. Box illustrates area shown in Figure 2a. Inset shows location of study area in southern Britain. Coordinates use the British National Grid and lie within the $100 \mathrm{~km}$ square SN.

excision of the Iapetus Ocean at around $420 \mathrm{Ma}$ (Soper $\&$ Woodcock, 2003). Dynamic changes in overall basin geometry during this period led to episodic intrabasinal uplift and subsidence, local compartmentalization and switching of sediment source areas and supply routes (e.g. Woodcock et al. 1996; Davies et al. 1997). Eustatic sea-level changes are thought to have been strongly influenced by the development of an ice sheet on the main Gondwanan palaeocontinent, which was located at high latitudes in the southern hemisphere during Late Ordovician and Early Silurian times (e.g. Loydell, 1998; Cocks \& Torsvik, 2002). Advance and retreat of land-based ice sheets is thought to have produced significant changes in sea level (e.g. Brenchley, 1988; Page et al. 2007).

This paper presents a new stratigraphic and architectural description of a previously unrecognized coarsegrained turbidite corridor, located to the $\mathrm{NW}$ of the town of Llanwrtyd Wells in Powys (Fig. 1), and herein termed the Nant Brianne turbidite system (Fig. 2a, b; Schofield et al. 2004; Davies et al. 2006). Interpretation of the system's evolution is considered in the context of previously described examples, and the interaction of contemporary tectonic, local- and globalscale base level changes. Together, these highlight the importance of differentiating eustatic and tectonic effects on base level when interpreting the stratigraphic architecture of ancient turbidite systems.

\section{Stratigraphic context}

The salient features of the Ashgill to middle Llandovery submarine slope apron succession, represented as a schematic vertical section in Figure $2 b$, have been described in detail by Davies et al. (1997; see also Schofield et al. 2004; Davies et al. 2006). In summary, this succession comprises an alternation between anoxic facies, comprising dark grey turbidite mudstones interlayered with prominent laminated hemipelagic mudstones (Cwmere Formation and Monograptus sedgwickii Shales Member) and oxic facies, of pale green-grey, strongly burrow mottled turbidite mudstone and hemipelagite (Mottled Mudstone Member, Derwenlas Formation and Rhayader Mudstones Formation).

Two contemporaneous, late Hirnantian to early Telychian, laterally derived, coarse clastic turbidite systems, the Caban-Ystrad Meurig system and Allt-y-clych Conglomerate, have been described to date (Fig. 1). The most extensive of these, the Caban-Ystrad Meurig system, crops out on the NW margin of the Tywi Lineament near the town of Rhayader, and is represented by a coeval succession exposed in the core of the Teifi Anticline (Lapworth, 1900; Jones, 1922; Kelling \& Woollands, 1969; Davies \& Waters, 1995; Davies et al. 1997; J. Holroyd, unpub. Ph.D. thesis, Univ. of Wales, Swansea, 1978). It was active from 

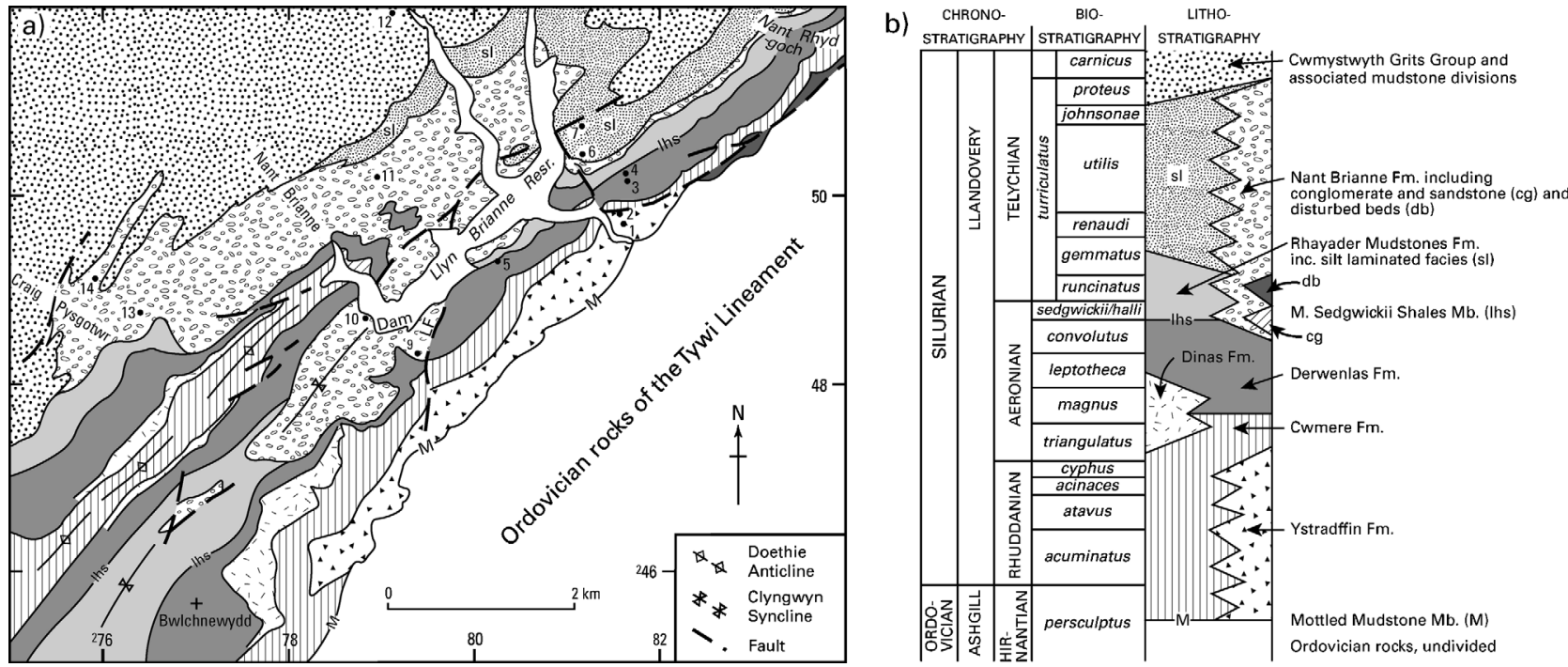

Figure 2. (a) Geological map illustrating the Nant Brianne turbidite system and host slope apron succession (after BGS, 2005, 2006). Numbered points refer to selected, dated graptolite localities detailed in Table 1. LF - Lynn Brianne Fault. (b) Schematic vertical section and key to ornaments and symbols in (a).

latest Ordovician (late Hirnantian) to early Telychian times and is interpreted as recording the deposition of a series of small, unconfined distributory fans (Ystrad Meurig Grits), supplied by a narrow channel-overbank system (Caban Conglomerate: Davies \& Waters, 1995; Davies et al. 1997; Davies, Waters \& Copus, 1999). The Allt-y-clych Conglomerate (Andrew, 1925), contained within the Rhuddanian proximal slope apron sequence, is preserved along the eastern margin of the Tywi Lineament and comprises a thin sequence that may link with the Caban-Ystrad Meurig system (Davies et al. 1997; Davies, Waters \& Copus, 1999).

The early Telychian parts of the Caban Conglomerate Formation, which post-date the Ystrad Meurig Grits, formed one of several supply routes to the early parts of the Devil's Bridge Formation (Davies et al. 2006), a turbidite system, up to $600 \mathrm{~m}$ in thickness, that blanketed much of the basin west of the Central Wales Lineament during early to middle Telychian times (Cave \& Hains, 1986; Davies et al. 1997; James, 2005).

Recent surveying by the British Geological Survey in the Builth Wells and adjacent Lampeter districts has revealed another broadly contemporaneous, easterly derived, coarse clastic turbidite system, transecting the same slope apron succession as the Caban-Ystrad Meurig system (Davies et al. 1997). It is located on the NW flank of the Tywi Lineament, centred on the Llyn Brianne dam [SN 795 485] (Schofield et al. 2004; Davies et al. 2006). The main depositional unit, the Nant Brianne Formation, takes its name from one of the tributaries to the SW arm of the reservoir, but the Nant Brianne turbidite system, as defined here, includes additional, sandstone-rich units and flanking facies also present in the vicinity (Fig. 2). Anoxic horizons within the succession favour preservation of graptolites. These have been used to provide a detailed biostratigraphic framework for the architecture of the Nant Brianne system. Key localities and ages are listed in Table 1 and plotted on Figures 2a and 3.

Coarse clastic sediments were first recognized in this area by K. A. Davies (1933). Mackie (A. H. Mackie, unpub. Ph.D. thesis, Univ. Cambridge, 1987, 1993; see also Mackie \& Smallwood, 1987) did not distinguish the Nant Brianne Formation sand body as a separate unit and included the equivalent strata principally in his Cefn Isaf and Llyn Brianne formations, but also locally in his Hafdre Formation; the latter has been shown to include rocks now recognized as part of the overlying, southerly sourced Cwmystwyth Grits Group (Davies et al. 2006). Nevertheless, much of the palaeocurrent and other directional data cited below concur with Mackie's findings.

\section{Nant Brianne turbidite system}

The main architectural features of the Nant Brianne system and its relationship with the enveloping slope apron succession are illustrated in Figure 3. As this system has not previously been described, sedimentological features of the component successions are presented in Appendix 1. The system rests locally on the basal Mottled Mudstone Member of the Cwmere Formation, which is of persculptus graptolite Biozone age, and provides an important stratigraphic datum. Beneath the Nant Brianne Formation, separate and in part older elements of the system comprise two sandstone-rich units here named the Ystradffin and Dinas formations. Upper levels of the Nant Brianne Formation pass laterally into a distinctive siltstone-rich flanking facies included in the Rhayader Mudstones Formation and are succeeded by divisions of the southerly sourced Cwmystwyth Grits Group (Schofield et al. 2004; Davies et al. 2006). 
Table 1. Summary of biostratigraphic age determinations

\begin{tabular}{|c|c|c|c|c|}
\hline Locality & NGR & BGS Specimen numbers & Fauna & Age \\
\hline 1 & SN 81674970 & MWL2964, 2965 & $\begin{array}{l}\text { Campograptus ex gr. communis (Lapworth, 1876) } \\
\quad \text { s.l.? } \\
\text { Rhaphidograptus toernquisti (Elles \& Wood, 1906) } \\
\text { Monograptus triangulatus (Harkness, 1851) s.l. } \\
\text { Glyptograptus? sp. }\end{array}$ & $\begin{array}{l}\text { Llandovery, Aeronian, } \\
\text { triangulatus or magnus } \\
\text { Biozone }\end{array}$ \\
\hline 2 & SN 81624975 & MWL2966-2970 & $\begin{array}{l}\text { Monograptus triangulatus s.l.? } \\
\text { Monograptus capis Hutt, } 1975 \\
\text { (or Monogr. involutus Lapworth, 1876) } \\
\text { Rhaphidograptus toernquisti? } \\
\text { Glyptograptus? sp. }\end{array}$ & $\begin{array}{l}\text { Llandovery, Aeronian, } \\
\text { probably triangulatus or } \\
\text { magnus Biozone }\end{array}$ \\
\hline 3 & SN 81645017 & $\begin{array}{l}\text { MWL1278-80, } \\
1362-71,1694-1714, \\
2004-2012,2957\end{array}$ & $\begin{array}{l}\text { Monograptus limatulus Törnquist, } 1892 \\
\text { Campograptus lobiferus lobiferus (M'Coy, 1850) } \\
\text { Campograptus lobiferus harpago (Törnquist, 1899) } \\
\text { Glyptograptus incertus (Elles \& Wood, 1907) } \\
\text { sensu Hutt, } 1974 \\
\text { Monograptus capis } \\
\text { Monograptus paradenticulatus Zalasiewicz, 1996? } \\
\text { Pristiograptus regularis (Törnquist, 1899)? } \\
\text { Streptograptus sp. nov. } \\
\text { Torquigraptus sp. (fragments) } \\
\text { Lagarograptus } \text { sp. } \\
\text { Metaclimacograptus? sp. }\end{array}$ & $\begin{array}{l}\text { Llandovery, Aeronian, } \\
\text { convolutus Biozone }\end{array}$ \\
\hline 4 & SN 81645018 & MWL2958-2961 & $\begin{array}{l}\text { Monograptus limatulus } \\
\text { Glyptograptus cf. incertus } \\
\text { graptolite fragments }\end{array}$ & $\begin{array}{l}\text { Llandovery, Aeronian, } \\
\text { convolutus Biozone }\end{array}$ \\
\hline 5 & SN 80334928 & MWL1677-1686 & $\begin{array}{l}\text { Stimulograptus sedgwickii } \\
\text { Metaclimacograptus cf. undulatus (Kurck, 1882) } \\
\text { Metaclimacograptus sp. } \\
\text { Campograptus? sp. } \\
\text { Torquigraptus? sp. (fragments) } \\
\text { Lagarograptus? sp. }\end{array}$ & $\begin{array}{l}\text { Llandovery, possibly the } \\
\text { Aeronian sedgwickii } \\
\text { Biozone s.l. }\end{array}$ \\
\hline 6 & SN 81185037 & $\begin{array}{l}\text { MWL1758-1767, } \\
\text { 1987-2003, 2404-2413, } \\
2484-2489\end{array}$ & $\begin{array}{l}\text { Streptograptus plumosus (Baily, 1871) } \\
\text { Streptograptus cf. filiformis Chen, 1984 } \\
\text { Stimulograptus glanfredensis Loydell, 1993? } \\
\text { Paradiversograptus cf. rectus (Manck, 1923) } \\
\text { Torquigraptus? sp. }\end{array}$ & $\begin{array}{l}\text { Llandovery, Telychian, } \\
\text { guerichi Biozone, } \\
\text { probably the runcinatus or } \\
\text { gemmatus Subzone }\end{array}$ \\
\hline 7 & SN 81195074 & $\begin{array}{l}\text { MWL1255-1259, } \\
1333-1342\end{array}$ & $\begin{array}{l}\text { Stimulograptus utilis Loydell, } 1991 \\
\text { Streptograptus cf. pseudoruncinatus } \\
\quad \text { (Bjerreskov, 1975) } \\
\text { Pristiograptus? sp. }\end{array}$ & $\begin{array}{l}\text { Llandovery, Telychian, utilis } \\
\text { Subzone }\end{array}$ \\
\hline 8 & SN 80755304 & $\begin{array}{l}\text { MWL1242-1244, } \\
1315-1328,1730-1741\end{array}$ & $\begin{array}{l}\text { Torquigraptus proteus (Barrande, 1850) or } \\
\text { carnicus (Gortani, 1923) } \\
\text { Petalolithus (kurcki-like) } \\
\text { Glyptograptus (tamariscus or fastigatus-like) } \\
\text { Pristiograptus? sp. } \\
\quad \text { hooked monograptid }\end{array}$ & $\begin{array}{l}\text { Llandovery, turriculatus } \\
\text { Biozone } \text { s.s., proteus or } \\
\text { carnicus } \text { Subzone }\end{array}$ \\
\hline 9 & SN 79354823 & MWL1816-1835, 1982 & $\begin{array}{l}\text { Campograptus lobiferus s.l. (some cf. lobiferus } \\
\text { harpago) } \\
\text { Metaclimacograptus } \mathrm{cf} . \text { bohemicus (Perner, 1897) } \\
\text { retiolitid sp. }\end{array}$ & $\begin{array}{l}\text { Llandovery, Aeronian, } \\
\text { probably convolutus } \\
\text { Biozone }\end{array}$ \\
\hline 10 & SN 78844867 & $\begin{array}{l}\text { MWL1847, 2337-2343, } \\
\text { 2935-2937 }\end{array}$ & $\begin{array}{l}\text { Paradiversograptus runcinatus (Lapworth, 1876) } \\
\text { graptolite fragments }\end{array}$ & $\begin{array}{l}\text { Llandovery, Telychian, } \\
\text { guerichi biozone, } \\
\text { probably the runcinatus } \\
\text { Biozone }\end{array}$ \\
\hline 11 & SN 78985012 & MWL1392, 1793-1798 & $\begin{array}{l}\text { Stimulograptus utilis } \\
\text { Torquigraptus } \mathrm{sp} .\end{array}$ & $\begin{array}{l}\text { Llandovery, Telychian, utilis } \\
\text { Subzone }\end{array}$ \\
\hline 12 & SN 79145194 & MWL1923-1932 & $\begin{array}{l}\text { Monograptus discus (Törnquist, 1883) } \\
\text { Monograptus bjerreskovae (Loydell, 1993) }\end{array}$ & $\begin{array}{l}\text { Llandovery, Telychian, } \\
\text { crispus Biozone }\end{array}$ \\
\hline 13 & SN 76434879 & $\begin{array}{l}\text { MWL5607-5634, } \\
5670-5685\end{array}$ & $\begin{array}{l}\text { Monograptus bjerreskovae (abundant) } \\
\text { Monograptus marri Perner, } 1897 \\
\text { Spirograptus turriculatus (Barrande, 1850) s.l. } \\
\text { Pristiograptus } \text { cf. pristinus Přibyl, 1940 } \\
\text { Torquigraptus planus (Barrande, 1850)? } \\
\text { Glyptograptus sp. }\end{array}$ & $\begin{array}{l}\text { Llandovery, Telychian, } \\
\text { renaudi or utilis Subzone }\end{array}$ \\
\hline 14 & SN 75954911 & $\begin{array}{l}\text { MWL5584-5606, } \\
5662-5669\end{array}$ & $\begin{array}{l}\text { Rastrites spengillensis Rickards, } 1970 \\
\text { Stimulograptus becki (Barrande, 1850) } \\
\text { Monograptus bjerreskovae } \\
\text { Torquigraptus proteus? }\end{array}$ & $\begin{array}{l}\text { Llandovery, Telychian, } \\
\text { possibly the proteus } \\
\text { Subzone }\end{array}$ \\
\hline
\end{tabular}

Locality numbers refer to Figures 2a and 3 of this paper only. Specimen numbers refer to BGS biostratigraphic collections. Full details of the relevant collections are listed in BGS reports IR/02/132 and IR/01/034R. 


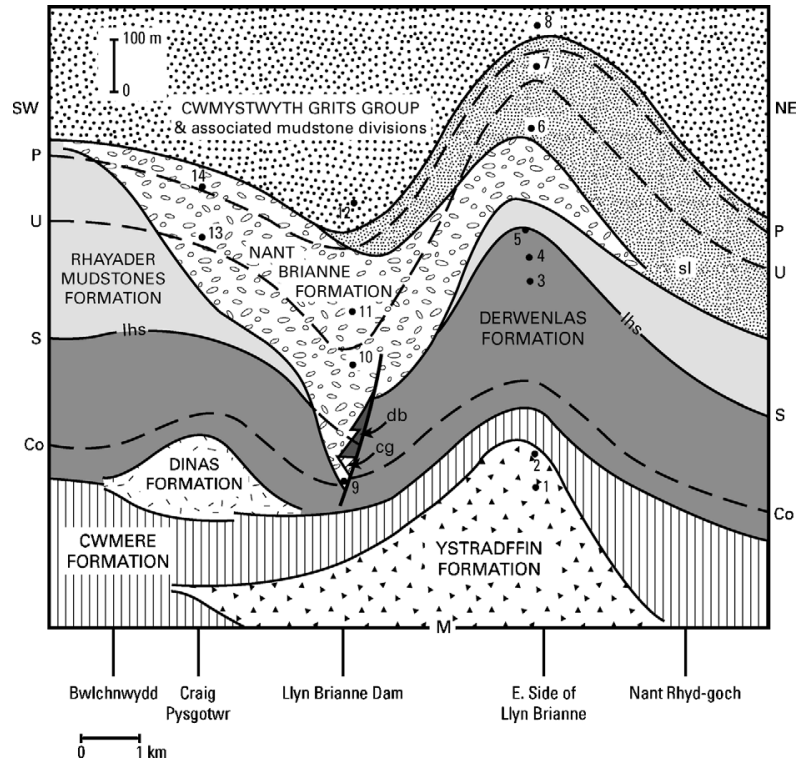

Figure 3. Cartoon illustrating the architecture of the Nant Brianne Formation and associated coarse clastic lenses. Indicative bases of selected biozones are shown as are selected graptolite localities, detailed in Table 1. Co - convolutus graptolite Biozone; S - sedgwickii graptolite Biozone; U utilis Subzone (turriculatus Biozone); $\mathrm{P}$ - proteus Subzone (turriculatus graptolite Biozone). See Figure $2 \mathrm{~b}$ for key to ornaments, symbols and chronostratigraphic relationships of the biozones.

\section{3.a. Ystradffin Formation}

This newly named division ranges from latest Ordovician (Hirnantian) to early Aeronian age and comprises up to $350 \mathrm{~m}$ of thinly interbedded sandstones and mudstones arranged in Bouma (1962) turbidite sequences (Fig. 4a). Lower levels of the formation succeed the
Mottled Mudstone Member. In the axis of the system, upper levels of the formation yield probable triangulatus graptolite Biozone assemblages (locality 2). Palaeocurrent vectors from the formation range from WSW to ENE, but are dominantly N- to NW-directed.

\section{3.b. Dinas Formation}

This spatially separate sandstone-rich sequence comprises up to $200 \mathrm{~m}$ of thinly interbedded turbidite sandstones and mudstones, laterally equivalent in its lower half to the adjacent Cwmere Formation. In contrast, burrowed hemipelagites and the presence of trace fossil casts on the bases of the sandstones show the upper part, up to $150 \mathrm{~m}$, of the formation to be oxic and coeval with the enveloping Derwenlas Formation. No graptolite faunas have been recovered from the Dinas Formation, but its stratigraphic relationship with the enveloping sediments support an early to middle Aeronian age, with marked lateral expansion of its oxic portion initiated in the late magnus graptolite Biozone.

\section{3.c. Nant Brianne Formation}

The Nant Brianne Formation, which crops out in the vicinity of the Llyn Brianne reservoir and dam [SN 795 485] (Fig. 2), ranges up to $410 \mathrm{~m}$ in thickness and records the middle Aeronian to middle Telychian evolution of the Nant Brianne turbidite system. The oldest (Aeronian) parts of the formation are confined within a narrow central zone located immediately to the west of the Llyn Brianne Fault. In this part of the succession, the formation contains units of turbidite conglomerate, and slumped strata (Figs 4b, 5), which
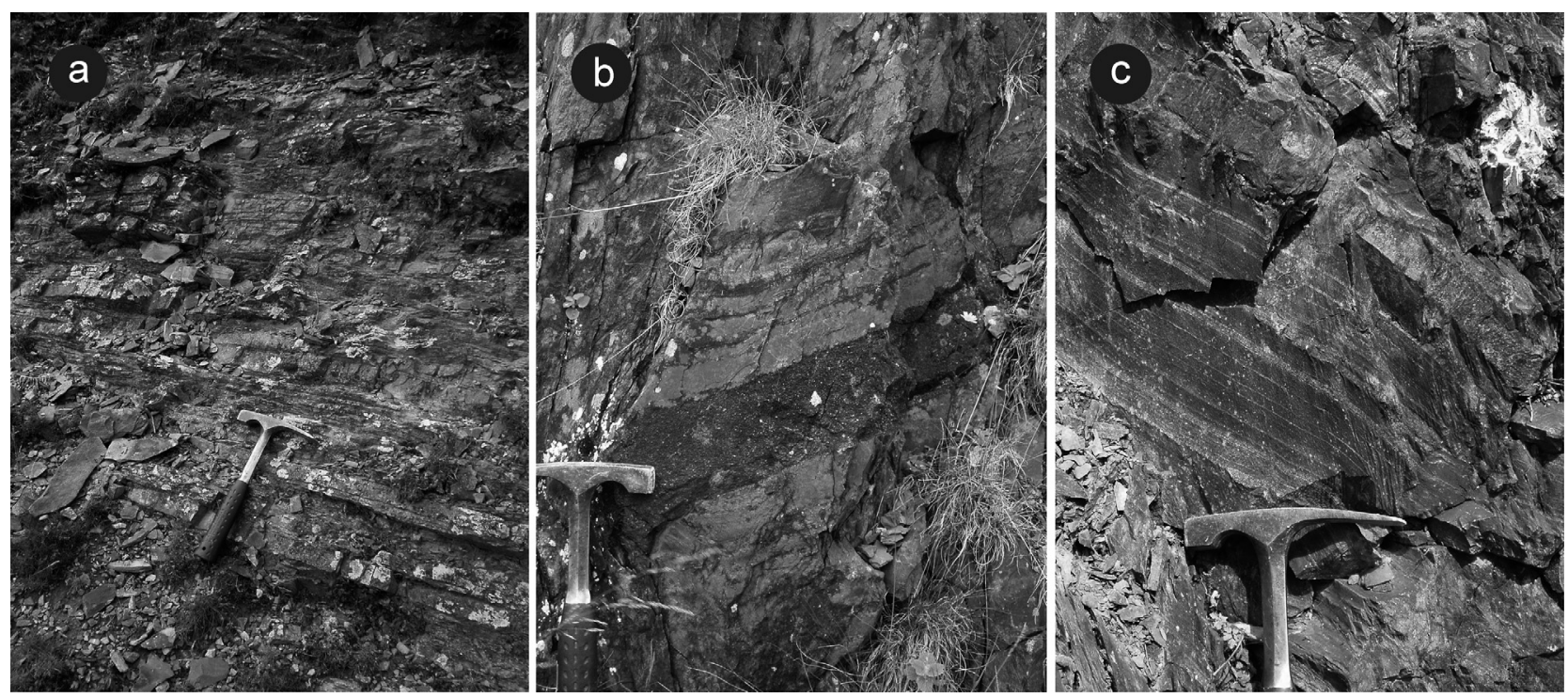

Figure 4. Field photographs showing: (a) Bouma turbidite sandstone-mudstone couplets, thicker beds display $\mathrm{T}_{\mathrm{b}-\mathrm{c}}$ sequences, thinner beds exclusively $T_{c}$ divisions, road cutting [SN 817 496], Ystradffin Formation. (b) Bouma turbidite sandstone-mudstone couplets; note coarse-grained sandstone $\mathrm{T}_{\mathrm{a}}$ division (by hammer head) rich in shell debris, Llyn Brianne dam access road [SN 793 483], Nant Brianne Formation. (c) Bouma turbidite sandstone-mudstone couplets; note basal, loaded-ripple $\mathrm{T}_{\mathrm{c}}$ division to left of hammer and planar-laminated $\mathrm{T}_{\mathrm{d}}$ divisions at base of mudstone-dominated couplets, Llyn Brianne dam access road [SN 793 482], basal Nant Brianne Formation. Hammer for scale is $\sim 0.28 \mathrm{~m}$ long. 


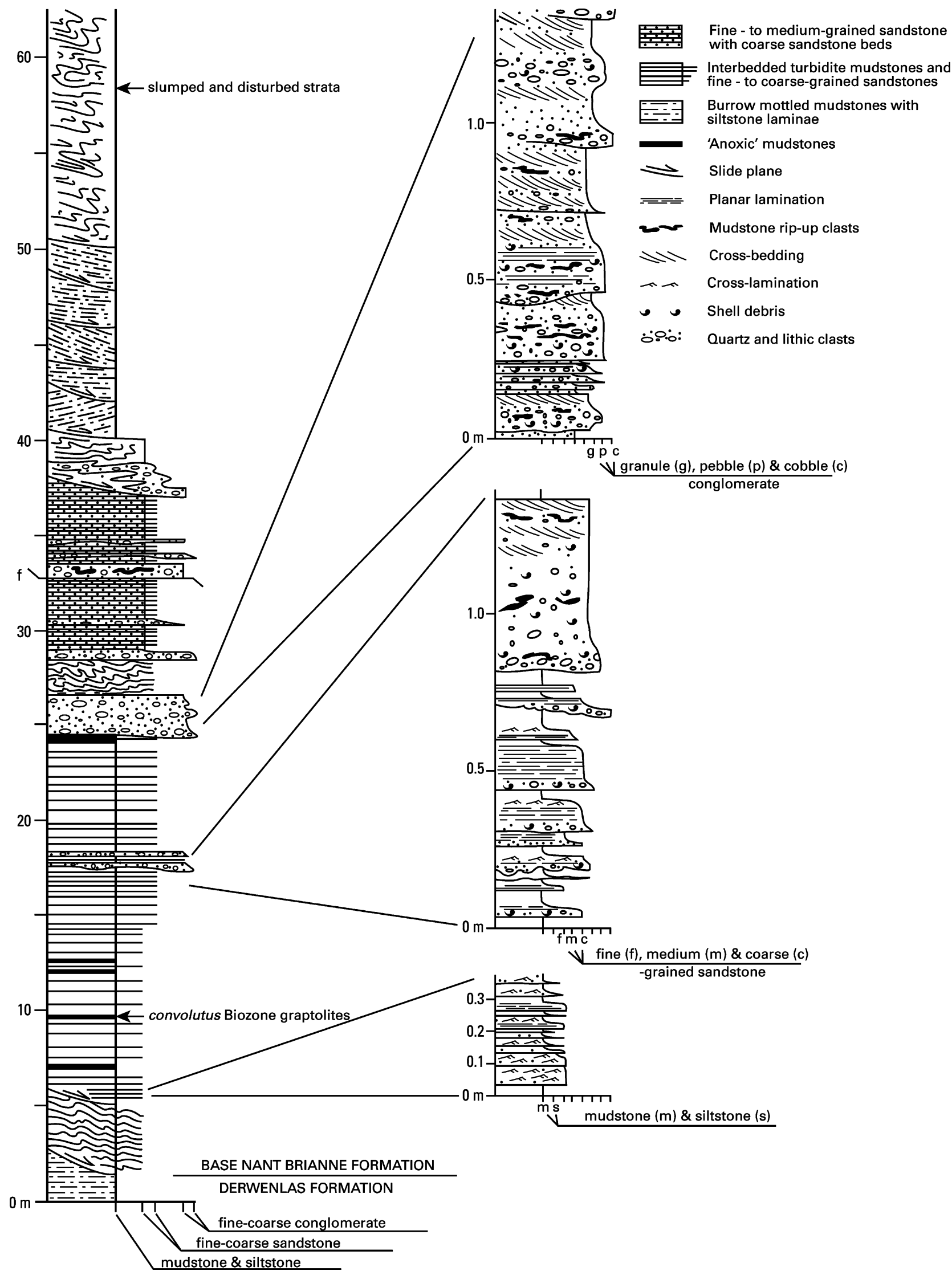

Figure 5. Graphic log of the lower part of Nant Brianne Formation as exposed in a continuous cutting on the eastern side of the Llyn Brianne dam access road between [SN 793 482] and [SN 793 484].

pass laterally into interbedded turbidite sandstones and mudstones arranged in Bouma-type couplets (Figs 4c, 5). However, the base of the formation is strongly diachronous, and during Telychian times a rapid lateral expansion occurred outwards from this central area (Fig. 3). In the upper part of the system, 
thinly interbedded turbidite sandstones and mudstones are interlayered with subordinate mudstone-dominated intervals, closely comparable to adjacent slope apron facies. Much thinner sequences occupy these western and eastern 'wings', but at their maximum, these younger levels of the formation occupy a $9 \mathrm{~km}$ wide belt. Palaeocurrent measurements in the vicinity of the Llyn Brianne Fault, including pebble orientations (after A. H. Mackie, unpub. Ph.D. thesis, Univ. Cambridge, 1987), indicate turbidity current flow mainly towards the NW, consistent with those for the formation as a whole. Slump fold axes in the adjacent disturbed sequence are oriented parallel to the NW-trending fault.

\section{Discussion}

\section{4.a. Local controls on turbidite system evolution}

The Nant Brianne system records the influence of seafloor topography on localizing deposition. In the lowest part of the system, Mackie (A. H. Mackie, unpub. Ph.D. thesis, Univ. Cambridge, 1987) envisaged his Clyn-glas Formation (approximately equivalent to the Ystradffin Formation of this account) as infilling a broad hollow, either a slump scar or a channel, formed during the late Ordovician fall in sea level. However, he did not recognize the presence of the Mottled Mudstone Member as a continuous datum beneath the Ystradffin Formation, which indicates that the latter shows no erosion at the base, and instead formed a positive, constructional feature on the contiguous slope apron surface (Fig. 3). The Dinas Formation may mark the site of a smaller, younger lobe, the location of which, offset to the south, was in part determined by the relief created by the earlier Ystradffin feature (cf. Davies \& Waters, 1995).

The early (Aeronian) part of the Nant Brianne Formation records a period of laterally confined sand and gravel deposition. Graptolites of the convolutus graptolite Biozone (locality 9) from within the formation and from anoxic levels within the Derwenlas Formation to the east of the Llyn Brianne Fault (localities 3 and 4) attest to dramatic lateral facies change across the fault and confirm that it formed a significant topographic feature at this time. It was thus probably instrumental in confining and accommodating the late Aeronian evolution of the Nant Brianne Formation. The relief created by the earlier Ystradffin and Dinas features, and a localized depocentre created by a probable linear half-graben formed by movement on the Llyn Brianne Fault (Fig. 3), were clearly instrumental in locating a narrow corridor in which gravels were deposited from highconcentration, surging and bottom-hugging turbidity flows (e.g. Pickering, Scott \& Hein, 1989; Hein \& Walker, 1982). This channelized belt was subsequently occluded or displaced by the foundering of adjacent slope apron muds along the active fault scarp.

The earliest parts of the Nant Brianne Formation east of the Llyn Brianne Fault overlie the Monograptus sedgwickii Shales Member and record the overtopping of the fault scarp, ending its role as a confining structure sometime during the Late Aeronian to Early Telychian (Fig. 3). The rapid expansion of the Nant Brianne Formation during Telychian times may record the reestablishment and advance of a lobe-like body above the earlier channelized units. However, it remained partially confined on its eastern flank, suggesting that deposition of this part of the formation was still influenced by sea-floor relief created previously by the Llyn Brianne Fault.

\section{4.b. High order eustatic controls}

Figure 6 illustrates the biostratigraphic range and lateral extent of the various Rhuddanian to Telychian coarse clastic bodies, relative to the slope apron sequence in which they are embedded. Within the slope apron sequences, the alternation of oxic and anoxic intervals may in some instances record key eustatic events of the late Hirnantian to early Telychian period, many of which may relate to the retreat and advance of a fluctuating Gondwanan ice sheet (Page et al. 2007). In Central Wales, two main transgressive-regressive cycles, defining two major sedimentary sequences, are recognized. The principal events and the local slopeapron responses were as follows:

(1) An initial late Hirnantian to Rhuddanian age major post-glacial rise in sea level which established anoxic slope apron conditions. This transgression was sustained throughout Rhuddanian times with a consensus that maximum flooding was achieved during the cyphus graptolite Biozone (e.g. Johnson, Kaljo \& Rong, 1991).

(2) An early Aeronian regression which introduced oxic slope apron facies. There is growing evidence to suggest that this event had its acme at or around the magnus-leptotheca biozonal boundary (e.g. Loydell, 1998).

(3) A late Aeronian transgression (or transgressions). An analysis of global data (Page et al. 2007) suggests that a global marine transgression occurred at the time of the convolutus graptolite Biozone, corresponding with thin units of anoxic facies mudstones of this age, recognized in the slope apron succession of the Welsh Basin (Davies et al. 1997). However, within the basin and on its contiguous shelf, together with records from other basinal successions from the Iapetus-Rheic ocean margin of Gondwana, there is clear evidence of a more marked and rapid rise in sea level around the start of the succeeding sedgwickii graptolite Biozone (Page et al. 2007 and references therein). The eustatic nature of this event is questioned (Page et al. 2007), but on the local slope apron it is clearly recorded by the widespread Monograptus sedgwickii Shales anoxic interval which correlates, at least in part, with an overstepping, Pentamerus-bearing 


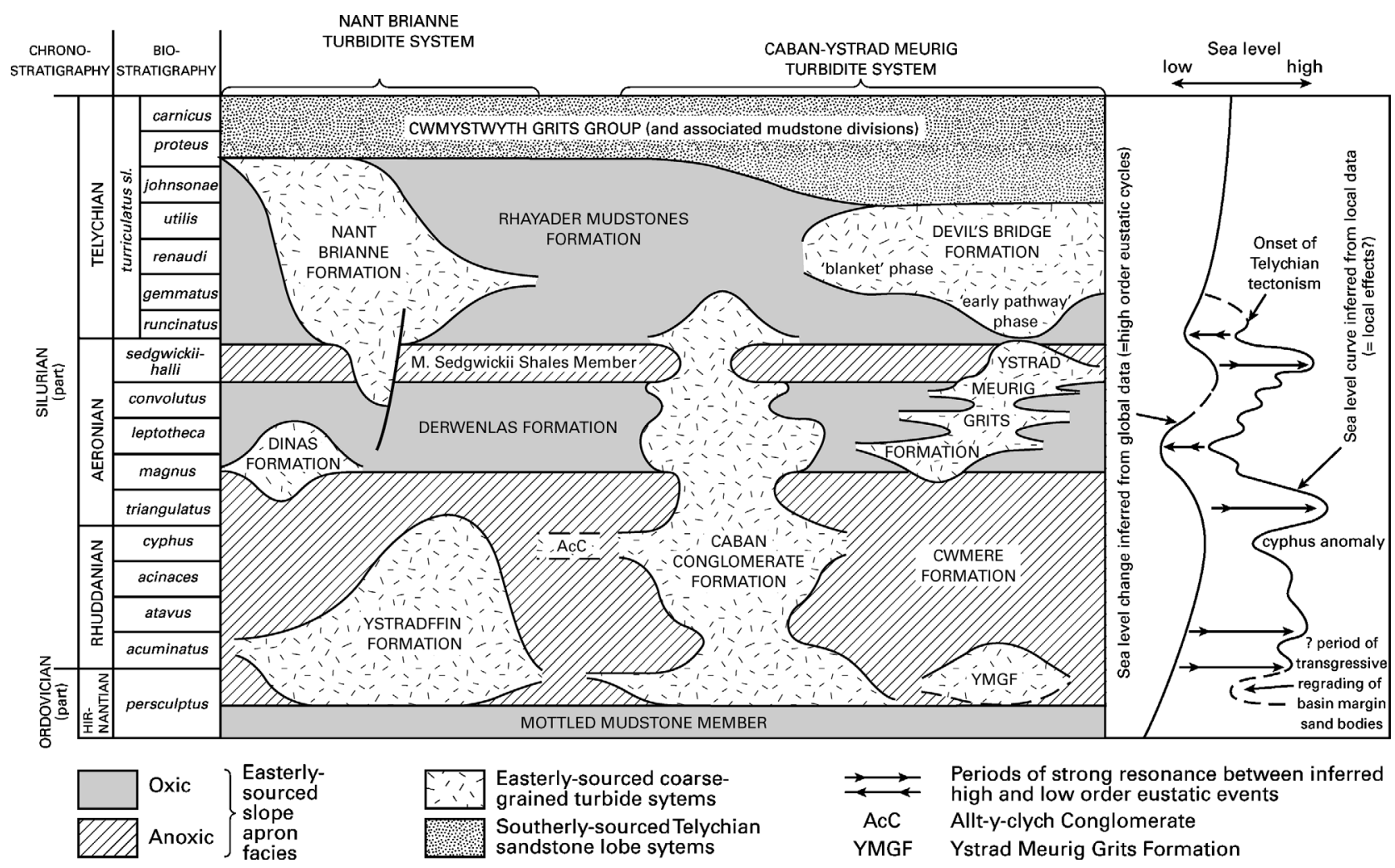

Figure 6. Regional architecture illustrating the biostratigraphic range and relative lateral extent of the Nant Brianne and Caban-Ystrad Meurig systems relative to the host slope apron succession.

sandstone bed in adjacent shelf sequences (Davies et al. 1997; Schofield et al. 2004).

(4) Global data provide evidence of a possible glacially induced regression during the sedgwickii graptolite Biozone. In the Welsh Basin, resumption of oxic slope apron deposition above the Monograptus sedgwickii Shales Member was perhaps the local response to this event. Predominantly oxic deposition, as recorded by the Rhayader Mudstones, was sustained throughout much of the ensuing early Telychian interval, but conflicts with evidence of rising global sea level at this time (Davies et al. 1997).

The geometry of the sand-rich systems reveals trends that are at odds with obvious eustatic influences. In particular, the outbuilding of lobes of sand-rich sediment during late Hirnantian to early Rhuddanian times (persculptus to acuminatus graptolite biozones), as represented by the Ystradffin Formation of the Nant Brianne system, and the Cerig Gwynion Grits of the Caban-Ystrad Meurig system, occurred during rapidly rising sea level. Although these may in part reflect higher frequency, lower order eustatic controls (see next Section), an alternative explanation for this is that these bodies are analogous to the 'slope front fills' identified on seismically imaged slope apron successions (e.g. Mitchell et al. 1993), and may record the reworking and basinward transport of sand previously carried onto the adjacent shelf during the preceding glacio-eustatic lowstand.
A comparable situation occurred with the expansion of the Caban-Ystrad Meurig system to its greatest lateral extent during a period of sea-level highstand, coincident with the cyphus graptolite Biozone (Davies $\&$ Waters, 1995). This expansion was accompanied by deposition of the Allt-y-clych Conglomerate and continued sedimentation in the Ystradffin tract.

A significant reduction of sediment input into both turbidite systems, which began in the late cyphus graptolite Biozone and lasted into the triangulatus graptolite Biozone, could reflect the delayed influence of the global transgression on sediment supply (see next Section). Certainly, the marked expansion during the succeeding magnus graptolite Biozone in both the Dinas and Caban Conglomerate formations, coinciding with the onset of oxic conditions across the adjacent slope apron (base Derwenlas Formation), can be interpreted as a response, at least in part, to the early Aeronian eustatic regression.

\section{4.c. Low order eustatic controls}

The coarse grade and large volume of clastic material supplied to the Nant Brianne and Caban-Ystrad Meurig systems, at times of eustatic sea-level rise, appears to support the suggestion that the detritus was generated in response to tectonic uplift in sediment source areas sited to the east of the basin (Woodcock et al. 1996; Davies et al. 1997). However, Davies, Waters \& Copus (1999) recognized a close comparison with the architectural elements of many hydrocarbonbearing deep-water basins, such as that described 
by Mitchell et al. (1993) for the Palaeocene of the Faeroe Basin. There, each episode of turbidite system expansion is correlated with a minor marine regression. Assuming that the patterns of sediment input are driven exclusively by base level changes and not variations in supply and/or the rate of subsidence, application of this model to the turbidite systems examined in this paper implies that a series of lower order events (Fig. 6), which influenced the flux of coarse-grade detritus entering the basin, were superimposed on the major eustatic cycles. When there was concordance between the smaller and larger eustatic cycles, typically ascribed to orbital forcing (e.g. Fischer \& Bottjer, 1991), the sediment supply could be predicted to be either especially high or low (Van Wagoner et al. 1990). The former was possibly the case during early Aeronian times, the latter during the sedgwickii Biozone.

The high levels of coarse clastic input during the cyphus graptolite Biozone at the height of the Rhuddanian post-glacial transgression remain an enigma. Viewed in isolation, it could be argued that this period of turbidite system expansion, as with the earlier Ystradffin and Cerig Gwynion Grits lobes, records the basinward transfer of sand and gravel as part of a regrading of the shelf edge; furthermore, this would have taken place during the early phases of a lower order transgression (Ross et al. 1994). However, coeval shelf successions also experienced increased levels of sand input at this time (Barclay et al. 2005; Cocks et al. 1984; Schofield et al. 2004), indicating that the pattern of deposition was controlled by marine regression. Subsequently, the global high sea-level conditions and a lower order base-level rise may have combined to abruptly limit the input of sediment during the marked triangulatus graptolite Biozone contraction.

\section{4.d. Regional tectonic controls}

The marked increase in the volume of sandy detritus supplied to the basin during deposition of the Telychian Series coincided with the onset of widespread tectonism throughout the basin and its hinterland (Woodcock et al. 1996), and contrasts with earlier, localized tectonic activity preserved in the Rhuddanian and Aeronian record of the basin margin (e.g. Woolhope and Usk basins: Woodcock et al. 1996; Butler, Woodcock \& Stewart, 1997). Any evidence for the influence of eustatic events is lacking, and it is clear that the detritus entering the basin was, at this time, dominantly tectonically generated. The Telychian expansion of the Nant Brianne system coincided with a marked reduction of the Caban-Ystrad Meurig system, suggesting that the latter was replaced by the former as the principal point of supply to the 'blanket phase' of the Devil's Bridge Formation (Fig. 1; see Davies et al. 1997). Faulting, both within the basin and along its margins, ultimately led to the abandonment of the Nant Brianne and Caban-Ystrad Meurig systems as their supply paths from the east were dislocated and the direction of sediment input to the basin switched to the south (Woodcock et al. 1996; Davies et al. 1997, 2006).

\section{Conclusions}

The newly recognized late Hirnantian to early Telychian Nant Brianne turbidite system represents a narrow corridor of laterally supplied, easterly sourced, coarse-grained deposits that punctuated a mudstonedominated slope apron, along the SE margin of the southern Welsh Basin. Application of high-precision graptolite biostratigraphy has shown that its evolution, and that of coeval coarse-grained systems, was influenced by a number of factors, including sea-floor topography and synsedimentary faulting. However, the interaction of high order eustatic events, related to fluctuation of contemporary Gondwanan ice sheets, with lower order, lower magnitude sea-level changes, appears to have been a critical influence on sedimentary architecture prior to the onset and overriding influence of Telychian age regional tectonism.

Acknowledgements. This work was carried out as part of the BGS' Central Wales Rapid Mapping Project. The authors would like to thank Alex Page for access to a proof version of Page et al. (2007) and Stuart Molyneux for providing useful comments on an earlier version of this manuscript. D. I. Schofield, J. R. Davies and D. Wilson publish with the permission of the Executive Director, British Geological Survey. Mark Williams thanks the University of Leicester for study leave.

\section{References}

ANDREW, G. 1925. The Llandovery rocks of Garth (Breconshire). Quarterly Journal of the Geological Society of London 81, 389-406.

BALl, T. K., DAVIES, J. R., WATERs, R. A. \& ZALASIEWICZ, J. A. 1992. Geochemical discrimination of Silurian mudstones according to depositional process and provenance within the Southern Welsh Basin. Geological Magazine 129, 567-72.

BAILY, W. H. 1871. Palaeontological remarks. In Explanatory memoir to accompany sheets 49, 50 and part of 61 of the Maps of the Geological Survey of Ireland including the country around Downpatrick, and the shores of Dundrum Bay and Strangford Lough, County of Down (eds W. A. Traill \& F. W. Egan), pp. 22-3. Dublin \& London: Alexander Thom, $71 \mathrm{pp}$.

Barclay, W. J., Davies, J. R., Humpage, A. J., Waters, R. A., Wilby, P. R., Williams, M. \& WiLSON, D. 2005. Geology of the Brecon district - a brief explanation of the geological map. Sheet explanation of the British Geological Survey. 1:50 000 Sheet 213 Brecon (England and Wales). Keyworth, Nottingham: British Geological Survey, $38 \mathrm{pp}$.

BARRAnde, J. 1850. Graptolites de Bohême. vi +74 pp., 4 pls. Prague.

BJERRESKOV, M. 1975. Llandoverian and Wenlockian graptolites from Bornholm. Fossils and Strata 8, 1-94.

BoumA, A. H. 1962. Sedimentology of some Flysch Deposits. Amsterdam: Elsevier, 168 pp.

BRENCHLEY, P. J. 1988. Environmental changes close to the Ordovician-Silurian boundary. Bulletin of the British Museum of Natural History (Geology) 43, 377-85. 
British Geological SuRVey. 2005. Builth Wells, England and Wales Sheet 196. Solid Geology. 1:50 000. Keyworth, Nottingham: British Geological Survey.

British GeOlogical SuRVEY. 2006. Lampeter, England and Wales Sheet 195. Bedrock and Superficial Geology. 1:50 000. Keyworth, Nottingham: British Geological Survey.

Butler, A. J., Woodcock, N. H. \& Stewart, D. M. 1997. The Woolhope and Usk Basins: Silurian rift basins revealed by subsurface mapping of the southern Welsh Borderland. Journal of the Geological Society, London 154, 209-23.

CAVE, R. \& Hains, B. A. 1986. Geology of the country between Aberystwyth and Machynlleth. Memoir of the British Geological Survey, Sheet 163 (England and Wales). Keyworth, Nottingham: British Geological Survey, $148 \mathrm{pp}$.

CHEN, X. 1984. Silurian graptolites from southern Shaanxi and northern Sichuan with special reference to classification of Monograptidae. Palaeontologica Sinica, New Series B 166(20), 1-102.

COCKS, L. R. M. \& ForTEY, R. A. 1982. Faunal evidence for oceanic separations in the Palaeozoic of Britain. Journal of the Geological Society, London 139, 467-80.

COCKS, L. R. M. \& TORSVIK, T. H. 2002. Earth geography from 500 to 400 million years ago: a faunal and palaeomagnetic review. Journal of the Geological Society, London 159, 631-44.

Cocks, L. R. M., WoOdCOCK, N. H., RickARds, R. B., TEMPle, J. T. \& LANE, P. D. 1984. The Llandovery Series of the Type Area. Bulletin of the British Museum (Natural History) 38, 131-82.

DAVIES, J. R. \& WATERS, R. A. 1995. The Caban Conglomerate and Ystrad Meurig Grits Formation - nested channels and lobe switching on a mud-dominated latest Ashgill to Llandovery slope-apron, Welsh Basin, UK. In Atlas of Deep Water Environments: Architectural style in turbidite systems (eds K. T. Pickering, R. N. Hiscott, N. H. Kenyon, F. Ricci Lucci \& R. D. A. Smith), pp. 184-93. London: Chapman and Hall.

Davies, J. R., Fletcher, C. J. N., WATERS, R. A., Wilson, D., Woodhall, D. G. \& Zalasiewicz, J. A. 1997. Geology of the country around Llanilar and Rhayader. Memoir of the British Geological Survey, Sheets 178 and 179 (England and Wales). Keyworth, Nottingham: British Geological Survey, 267 pp.

DAVIES, J. R., WATERS, R. A. \& Copus, J. 1999. Facies and geometry of deep-water turbidite systems in the Lower Palaeozoic Welsh Basin. AAPG International Conference (Birmingham), Field Trip 2: 8-11 September. British Geological Survey Technical Report (WA/99/095).

DAVIES, J. R., SCHOFIELD, D. I., SHEPPARD, T. H., WATERS, R. A., WILliAMS, M. \& WILSON, D. 2006. Geology of the Lampeter district - a brief explanation of the geological map. Sheet explanation of the British Geological Survey. 1:50 000 Sheet 195 Lampeter (England and Wales). Keyworth, Nottingham: British Geological Survey, $34 \mathrm{pp}$.

DAVIES, K. A. 1933. The geology of the country between Abergwesyn (Breconshire) and Pumpsaint (Carmarthenshire). Quarterly Journal of the Geological Society of London 89, 172-201.

Elles, G. L. \& Wood, E. M. R. 1906. A monograph of British graptolites. Edited by C. Lapworth. Part 5. Monograph of the Palaeontographical Society, London, 1xxviii-xcvi, 181-216.
Elles, G. L. \& Wood, E. M. R. 1907. A monograph of British graptolites. Edited by C. Lapworth. Part 6 . Monograph of the Palaeontographical Society, London, xcvii-cxx, 217-72.

FISCHER, A. G. \& BOTTJER, D. J. 1991. Orbital forcing and Sedimentary Sequences, Introduction. Journal of Sedimentary Petrology 61, 1063-9.

GorTAni, M. 1923. Contribuzioni allo studio del Paleozoico Carnico. Partie VII. Faune a Graptoliti. Palaeontographica Italica 26, 1-56.

HARKNESS, R. 1851. Description of the graptolites found in the black shales of Dumfriesshire. Quarterly Journal of the Geological Society of London 7, 58-65.

HeIN, F. J. \& WALKER, R. G. 1982. The Cambro-Ordovician Cap Enrage Formation, Quebec, Canada: conglomerate deposits of a braided submarine channel with terraces. Sedimentology 29, 309-29.

HutT, J. A. 1974. The Llandovery graptolites of the English Lake District. Part 1. Monograph of the Palaeontographical Society, London 128, 1-56.

HutT, J. A. 1975. The Llandovery graptolites of the English Lake District. Part 2. Monograph of the Palaeontographical Society, London 129, 57-137.

JAMES, D. M. D. 2005. Palaeotopography of the northern portion of the Telychian (Silurian) turbidite basin in central Wales. Geological Journal 40, 593601.

Johnson, M. E., KalJo, D. \& RonG, J.-Y. 1991. Silurian eustacy. In The Murchison Symposium; proceedings of an international conference on the Silurian System (eds M. G. Bassett, P. D. Lane \& D. Edwards), pp. 145-63. Special Papers in Palaeontology no. 44.

JONES, O. T. 1922. Lead and Zinc. The mining district of north Cardiganshire and west Montgomeryshire. Memoirs of the Geological Survey, Special Reports on the Mineral Resources of Great Britain 20. London: HMSO, $207 \mathrm{pp}$.

Kelling, G. \& Woollands, M. A. 1969. The stratigraphy and sedimentation of the Llandoverian rocks of the Rhayader district. In The Pre-Cambrian and Lower Palaeozoic rocks of Wales (ed. A. Wood), pp. 255-81. Cardiff: University of Wales Press.

KURCK, C. 1882. Några nya Graptolitarter från Skåne. Geologiska Föreningens i Stockholm Förhandlingar 6, 294-304.

LAPWORTH, C. 1876. On Scottish Monograptidae. Geological Magazine (Decade 2) 3, 308-21, 350-69, 499507, 544-52.

LAPWORTH, C. 1900. The Silurian sequence of Rhayader. Quarterly Journal of the Geological Society of London 56, 67-137.

LOWE, D. R. 1982. Sediment gravity flows: II. Depositional models with special reference to the deposits of highdensity turbidity currents. Journal of Sedimentary Petrology 52, 279-97.

LOYDELL, D. K. 1991. The biostratigraphy and formational relationships of the upper Aeronian and lower Telychian (Llandovery, Silurian) formations of western mid Wales. Geological Journal 26, 209-44.

LOYDELL, D. K. 1993. Upper Aeronian and lower Telychian (Llandovery) graptolites from western mid-Wales. Part 2. Monograph of the Palaeontographical Society, London 147, 56-180.

LOYDELL, D. K. 1998. Early Silurian sea-level changes. Geological Magazine 135, 447-71.

MACKIE, A. H. 1993. The Ordovician and Llandovery strata in the Llanwrtyd Wells to Llyn Brianne area. 
In Geological excursions in Powys, Central Wales (eds N. H. Woodcock \& M. G. Bassett), pp. 259-79. Cardiff: University of Wales Press, National Museum of Wales.

Mackie, A. H. \& SMallwood, S. D. 1987. A revised stratigraphy of the Abergwesyn-Pumpsaint area. Geological Journal 22, 45-60.

MANCK, E. 1923. Untersilurische Graptolithenarten der Zone 10 des Obersilurs, ferner Diversograptus gen. nov. sowie einige neue Arten anderer Gattungen. Natur, Leipzig 14, 282-9.

M'CoY, F. 1850. On some new genera and species of the Silurian Radiata in the collection of the University of Cambridge. Annals and Magazine of Natural History (2) 6, 270-90.

Melchin, M. J., CoOper, R. A. \& SADler, P. M. 2004. The Silurian Period. In A Geologic Time Scale 2004 (eds F. M. Gradstein, J. G. Ogg \& A. G. Smith), pp. 165-87. Cambridge: Cambridge University Press.

Mitchell, S. M., Beamish, G. W. J., Wood, M. V., MaleceK, S. J., Armentrout, J., DAmuth, J. E. \& OLSON, H. C. 1993. Palaeogene sequence stratigraphic framework of the Faeroe Basin. In Petroleum Geology of northwest Europe: Proceedings of the 4th Conference (ed. J. R. Parker), pp. 1011-23. London: Geological Society.

Morton, A. C., Davies, J. R. \& Waters, R. A. W. 1992. Heavy minerals as a guide to turbidite provenance in the Lower Palaeozoic Southern Welsh Basin: a pilot study. Geological Magazine 129, 573-80.

Page, A., Zalasiewicz, J., Willams, M. \& Popov, L. E. 2007. Were transgressive black shales a negative feedback modulating glacioeustacy in the Early Palaeozoic Icehouse. In Deep time perspectives on climate change: marrying the signal from computer models and biological proxies (eds M. Williams, A. M. Haywood, F. J. Gregory \& D. N. Schmidt), pp. 123-56. The Micropalaeontological Society. Bath: Geological Society Publishing House.

PERnER, J. 1897. Études sur les Graptolites de Bohême. Ilième Partie. Monographie des Graptolites de L'Etage E, Section a, 1-25, pls 9-13. Prague

Pickering, K. T., Hiscott, R. N. \& HeIN, F. J. 1989. Deep marine environments: clastic sedimentation and tectonics. London: Unwin Heiman, 416 pp.

PřIBYL, A. 1940. O českých zastupcích monograptid ů že skupiny Pristiograptus nudus. Rozpravy II. Tř Akademie 50(16), 1-14.

RICKARDS, R. B. 1970. The Llandovery (Silurian) graptolites of the Howgill Fells (Northern England). Monograph of the Palaeontographical Society, London, $108 \mathrm{pp}$.

Ross, W. C., Halliwell, B. A., MaY, J. A., Watts, D. E. \& SYviTSKI, J. P. M. 1994. Slope readjustment: A new model for the development of submarine fans and aprons. Geology 22, 511-14.

SChOFIElD, D. I., DAVIES, J. R., Waters, R. A., Wilby, P. R., Williams, M. \& Wilson, D. 2004. Geology of the Builth Wells district - a brief explanation of the geological map. Sheet explanation of the British Geological Survey. 1:50 000 Sheet 196 Builth Wells (England and Wales). Keyworth, Nottingham: British Geological Survey, 34 pp.

SoPer, N. J. \& HutTON, D. H. W. 1984. Late Caledonian sinistral displacements in Britain: implications for threeplate collision model. Tectonics 3, 781-94.

SOPER, N. J. \& WoODCOCK, N. H. 2003. The lost Lower Old Red Sandstone of England and Wales: a record of post-Iapetan flexure or Early Devonian transtension? Geological Magazine 140, 627-47.

Stow, D. A. V. \& PIPER, D. J. W. 1984. Deep-water fine-grained sediments: facies models. In Fine-grained sediments: deep-water processes and facies (eds D. A. V. Stow \& D. J. W. Piper), pp. 611-46. Geological Society of London, Special Publication no. 15.

TÖRNQUIST, S. L. 1883. Öfversigt öfver bergbygnaden inom Siljansområdets graptoliter. 1. Lunds Universitets Arsskrifter 26, 1-33.

TÖRNQUIST, S. L. 1892. Undersökningar öfver Siljansområdets graptoliter. Lunds Universitets Arsskrifter 28, 1-47.

TÖRNQUIST, S. L. 1899. Researches into the Monograptidae of the Scanian Rastrites Beds. Lunds Universitets Arsskrifter 35, 1-25.

VAN WagOner, J. C., MitchuM, R. M. JR, CAMPION, K. M. \& RAHMANIAN, V. D. 1990. Siliciclastic sequence stratigraphy in well logs, cores, and outcrops. Methods in Exploration, 7. Tulsa: American Association of Petroleum Geologists, $55 \mathrm{pp}$.

WoodCOCK, N. H. 1984. Early Palaeozoic sedimentation and tectonics in Wales. Proceedings of the Geologist's Association 95, 323-35.

Woodcock, N. H. \& GibBons, W. 1988. Is the Welsh Borderlands Fault system a terrane boundary? Journal of the Geoogical Society, London 145, 915-23.

Woodcock, N. H., Butler, A. J., Davies, J. R. \& Waters, R. A. 1996. Sequence stratigraphical analysis of late Ordovician and early Silurian depositional systems in the Welsh Basin: a critical assessment. In Sequence stratigraphy in British geology (eds S. P. Hesselbo \& D. N. Parkinson), pp. 197-208. Geological Society of London, Special Publication no. 103.

Woodcock, N. H., Soper, N. J. \& Strachan, R. A. 2007. A Rheic cause for the Acadian deformation in Europe. Journal of the Geological Society, London 164, 102336.

ZALASIEWICZ, J. A. 1996. Aeronian (Silurian: Llandovery) graptolites from central Wales. Geologica et Palaeontologica 30, 1-14.

Appendix 1. Detailed description of rock units and facies (see main text for additional data)

Ystradffin Formation. The formation attains its maximum thickness in its type area between Ystradffin Farm [SN 788 466] and an inlet of the Llyn Brianne Reservoir [SN 816 495] and passes laterally into the enveloping slope apron mudstone succession (Cwmere Formation). It extends laterally, along strike for a distance of $8.5 \mathrm{~km}$ and incorporates some of the sections described in detail by A. H. Mackie (unpub. Ph.D. thesis, Univ. Cambridge, 1987) and included in his Clyn Glas Formation (see also Mackie \& Smallwood, 1987).

A single lithofacies of thin- to medium-bedded turbidite sandstones, interbedded with thin turbidite and hemipelagic mudstones was recognized within the formation (Fig. 4a). This is characterized by tabular sandstone beds, up to $0.3 \mathrm{~m}$ thick, that form the basal division of sandstone-mudstone couplets. Base-cut-out $\mathrm{T}_{\mathrm{b}-\mathrm{e}}$ and $\mathrm{T}_{\mathrm{c}-\mathrm{e}}$ sequences predominate (Bouma, 1962), while graded basal $\mathrm{T}_{\mathrm{a}}$ divisions, including complete $\mathrm{T}_{\mathrm{a}-\mathrm{e}}$ sequences and top-cut-out $\mathrm{T}_{\mathrm{a}-\mathrm{b}}$ sequences, are rare. Turbidite mudstone $\left(T_{e}\right)$ intervals range up to $0.15 \mathrm{~m}$ in thickness. Many of the sandstones display convolute lamination. Sections in the east of the formation measured by Mackie (A. H. Mackie, unpub. Ph.D. thesis, Univ. Cambridge, 
1987) include a series of small-scale $(<10 \mathrm{~m})$ thinning- and fining-upwards cycles. The thickest turbidite sandstone beds occur in the lower part of the formation, where the sandstone content ranges up to $60 \%$.

Dinas Formation. The type locality of this unit are the crags south of the Afon Tywi [SN 774 458]. Laminated hemipelagites present in the lower, anoxic levels are restricted to the south of Dinas [SN 780 465], but the oxic portion is more widespread and forms the whole of the sandstone-rich sequence on, and to the north, of this prominent rock buttress. The oxic levels also crop out to the NW along both limbs of the Doethie Anticline (Fig. 2). Its geometry suggests that depositing turbidity currents flowed predominantly towards the NW.

The formation comprises a facies of thin-bedded turbidite sandstones, interbedded with thin turbidite and hemipelagic mudstones characterized by tabular and lenticular turbidite sandstones, up to $0.1 \mathrm{~m}$ thick that are typically planaror cross-laminated and form part of turbidite sandstonemudstone couplets $\left(\mathrm{T}_{\mathrm{b}-\mathrm{e}}\right.$ and $\mathrm{T}_{\mathrm{c}-\mathrm{e}}$; Bouma, 1962).

Nant Brianne Formation. Road cuttings to the east of the Llyn Brianne dam provide a section [SN 793 482] through the oldest (Aeronian) levels of the Nant Brianne Formation. At this stratigraphic level, the formation occupies a $2 \mathrm{~km}$ wide belt confined on its eastern side by the Llyn Brianne Fault. In the section adjacent to the dam access road (Fig. 5), a basal sequence of slumped and disturbed strata passes up into a $17 \mathrm{~m}$ thick unit of Bouma sandstone-mudstone couplets (Fig. 4c), including a thin unit with anoxic hemipelagites. These are overlain by a $3 \mathrm{~m}$ thick unit composed of medium to thick beds of turbidite conglomerate and pebbly sandstone (Fig. 4b). Conglomeratic facies are also seen in river cliffs [SN 480 785] to the SW of the Llyn Brianne dam. The conglomeratic beds of the access road section are succeeded by a sequence, up to $100 \mathrm{~m}$ thick, of slumped and disturbed strata (Figs 2,3) that also occupies a narrow belt adjacent to the Llyn Brianne Fault. The mudstone-dominated parts of the disturbed sequence resemble the oxic slope apron facies which crop out to the east of the Llyn Brianne Fault.

The upper (Telychian) part of the Nant Brianne Formation comprises rhythmically interlayered thin- to medium-bedded turbidite sandstones and mudstones. The lower part of this sequence comprises about $50 \%$ sandstone with individual beds up to $0.5 \mathrm{~m}$ thick. Above this the sequence comprises a crudely thinning- and fining-upwards succession in which the sandstone content diminishes to as little as $10 \%$. Packets of strata essentially identical to enveloping slope apron facies are also present throughout the upper part of the formation. This part of the sequence crops out between the Llyn Brianne Reservoir and Craig Pysgotwr, occupying both limbs of the Doethie Anticline and the core of the Cilgwyn Syncline (Fig. 2). The eastern 'wing' of the formation extends some $5 \mathrm{~km}$ beyond the fault and ranges up to $200 \mathrm{~m}$ in thickness. Traced NE toward Nant Rhyd Goch it becomes thinner and its base younger, and its upper parts pass laterally into a distinctive siltstone-laminated facies of the Rhayader Mudstones that has yielded graptolites of early to middle Telychian (turriculatus graptolite Biozone) age (localities 6 and 7). To the SW, between Llyn Brianne dam and Bwlchnewydd, the base of the formation is diachronous above the datum of the Monograptus sedgwickii
Shales Member and represents part of a SW expansion of the system which mirrors that to the east (Fig. 3). Early to middle Telychian turriculatus Biozone graptolites have been recovered from anoxic hemipelagites preserved within this western 'wing', on Craig Pysgotwr (localities 13 and 14)

The Nant Brianne Formation comprises three sedimentary lithofacies:

(a) The confined lower part of the formation predominantly comprises medium- to thick-bedded turbidite conglomerate and pebbly sandstone. The conglomerates are poorly sorted and include well-rounded clasts, up to $0.1 \mathrm{~m}$ in diameter, composed of vein quartz, igneous and sedimentary rock types, in a matrix of coarsegrained sandstone; mudstone rip-up clasts, abraded and broken shelly fossils, including corals, are common. Normally graded beds above a locally channelized base record the rapid deposition from high concentration gravel-laden gravity flows (R3; Lowe, 1982). Rare crossstratification (S1) and planar lamination (S2) visible in the sandier upper parts of some beds indicate tractional processes that were operative during the later phases of deposition, but structureless sandstone intervals (S3) that were deposited from suspension are more common. At the margins of this facies a basal conglomerate layer, commonly rich in shell debris, is succeeded by an upward-fining sandstone displaying well-developed planar- and cross-laminated divisions $\left(\mathrm{T}_{\mathrm{a}-\mathrm{c}}\right)$.

(b) Disturbed beds, which succeed the conglomeratic facies in the vicinity of the Llyn Brianne Fault, comprise a lower unit of highly contorted and disrupted mudstones, with isolated pillows of conglomerate and sandstone, and a thicker upper unit of slump-folded and destratified mudstone which displays abundant evidence of smallscale synsedimentary faulting and down-slope sliding (Mackie \& Smallwood, 1987).

(c) The bulk of the formation comprises thin- to mediumbedded turbidite sandstones interbedded with thin turbidite and hemipelagic mudstones. In this facies, some of the thicker sandstone beds form part of complete Bouma sequences $\left(\mathrm{T}_{\mathrm{a}-\mathrm{e}}\right)$, in which the normally graded and coarser-grained $\mathrm{T}_{\mathrm{a}}$ division commonly infills shallow scours, but most of the sandstones are tabular, mediumto fine-grained, and display planar-laminated $\left(\mathrm{T}_{\mathrm{b}}\right)$ and/or cross- or convolute-laminated $\left(\mathrm{T}_{\mathrm{c}}\right)$ intervals. Siltstone laminae $\left(\mathrm{T}_{\mathrm{d}}\right)$ are commonly present at the base of the succeeding mudstone Te division. Many of these beds contain fine shell debris and preserve the casts of trace fossils, together with tool marks and groove casts on the bases of most beds, although flute casts are less common. In the upper levels of this sequence, the sandstone/mudstone couplets predominantly comprise $\mathrm{T}_{\mathrm{c}-\mathrm{e}}$ sequences. Planar-laminated $\mathrm{T}_{\mathrm{b}}$ divisions are rare and $\mathrm{T}_{\mathrm{a}}$ divisions are absent. Turbidites composed exclusively of the mudstone $T_{e}$ division, with or without a basal $T_{d}$ interval, increase in importance and are the principal component of thin, mudstone-dominated packets in the uppermost parts of the formation. Many of these include a basal, cross- and planar-laminated siltstone interval, display the features described by Stow \& Piper (1984) and are the product of deposition from very low concentration turbidity currents. 